The Standing Commission of the Red Cross and Red Crescent met on 17 and 18 October under the chairmanship of Dr. A. Abu Goura. On the basis of Resolution XXVI of the 1986 International Conference of the Red Cross, the Commission decided that the Twenty-sixth International Conference of the Red Cross and Red Crescent would be held in Cartagena, Colombia, in October 1991. The Commission adopted regulations for the Red Cross and Red Crescent Prize for Peace and Humanity, the first of which will be awarded, in accordance with the 1987 Council of Delegates Resolution 1, during the Council of Delegates meeting in 1989, the Movement's 125th anniversary.

Note: Reports on the Nineteenth Conference of Arab National Red Crescent and Red Cross Societies (Cairo, 5-9 November 1988) and of the Pan-African Conference of Red Cross and Red Crescent Societies (Dakar, 21-23 November 1988) will be included in the next issue of the Review.

\title{
Recognition of the Mozambique Red Cross Society
}

Circular No. 550

Geneva, 24 October 1988

To the Central Committees of the National Red Cross

and Red Crescent Societies

\section{LADIES AND GENTLEMEN,}

We have the honour of informing you that the Mozambique Red Cross Society has been officially recognized by the International Committee of the Red Cross. This recognition, which took effect on 29 September 1988, brings to 147 the number of National Societies that are members of the International Red Cross and Red Crescent Movement.

Founded on 10 July 1981, the Society officially applied for recognition by the International Committee of the Red Cross on 23 September 1988. In support of its application, it forwarded various documents, including a report on its activities, the text of its Statutes and a copy 
of Government Decree No. 7/88 of 17 May 1988 attesting that the Mozambique Red Cross Society is recognized by the Government as a voluntary aid society auxiliary to the public authorities in accordance with the provisions of the First Geneva Convention of 1949.

These documents, which were examined jointly by the International Committee and the Secretariat of the League of Red Cross and Red Crescent Societies, showed that the ten conditions for the recognition of a new National Society by the International Committee may be considered as fulfilled.

The International Committee and the League have observed very closely the activities of the Mozambique Red Cross Society for several years. Representatives of the two institutions have ascertained that the Mozambique Red Cross Society has a sound infrastructure which enables it to extend its activities to every province in the country. These activities are being developed in several spheres: efforts to improve public health through health education and first-aid training, blood transfusion, assistance to adversely affected civilian population and to displaced persons, and the organization of information seminars at the national level.

On 14 March 1983, the Swiss Federal Council received notification of the accession by the People's Republic of Mozambique to the Geneva Conventions of 12 August 1949, which therefore entered into force on the territory of Mozambique on 14 September 1983.

The Mozambique Red Cross Society is presided over by Mr. José Moiane and its Secretary General is Mrs. Janet Mondlane. Its headquarters is located in Maputo. The address is as follows: Cruz Vermelha de Moçambique, Caixa Postal 2986, Maputo.

The International Committee of the Red Cross has pleasure in welcoming the Mozambique Red Cross Society to membership of the International Red Cross and Red Crescent Movement, in accrediting it and commending it, by this circular, to all other National Societies, and in expressing sincere good wishes to the Society for its future and for the success of its humanitarian work.

For THE INTERNATIONAL COMMITTEe OF THE RED CROSS

\section{Cornelio Sommaruga}

President 